\title{
Ověření Českého imisního testu
}

\section{JIŘí ŠAJER}

Klíčová slova: mísicí zóny - konzervativní znečištění - jakost vody - modelování

\section{SOUHRN}

Na vybraných údajích uvedených v obnoveném povolení k vypouštění odpadních vod pro objekt KB Alloys z 20. května 2010 [1] bylo ověřováno, k jakým výsledkům by při stejném zadání dospěl Český imisní test (CIT) [2]. Faktory ž̌edění získané pomocí modelu CIT byly približně stejné jako faktory zředění, které na základě stejných vstupních hodnot odvodil model RIVPLUM použitý jako podklad pro obnovení povolení.

\section{ÚVOD}

Podnik KB Alloys, LLC., ve Wenatchee je umístěn přibližně sedm mil jihovýchodně od Wenatchee na jih od řeky Columbia, do níz vypouští odpadní vody. Situace vypouštění je zobrazena na obr. 1. V pưvodním povolení k vypouštění odpadních vod před více než deseti lety byly pro objekt KB Alloys vymezeny faktory zředění. Způsob odvození v původním dokumentu nebyl jasně vysvětlen, takže není zřejmé, jakým způsobem byly hodnoty odvozeny. Proto byl proveden pokus simulovat podmínky pomocí modelu CORMIX 6, avšak tento software nedokáže modelovat mnohovýtokový difuzér umístěný v menší vzdálenosti od břehu, než je hloubka v řece. Z toho důvodu bylo přistoupeno k simulaci pomocí modelu RIVPLUM. Model RIVPLUM však vychází z předpokladů, které nejsou doporučovány pro tak široké toky, jako je řeka Columbia. Přesto však za použití stejných podmínek odvodil RIVPLUM faktory zředění srovnatelné s těmi, které byly uvedeny $v$ původním povolení k vypouštění odpadních vod. Vzhledem k tomu, že faktory ž̌edění byly používány více než 10 let, a na základě skutečnosti, velikosti relativního vypouštění k průtoku v řece i výsledků modelu RIVPLUM byly původní faktory zředění zachovány i v nově navrhovaném povolení k vypouštění odpadních vod. Na vybraných údajích uvedených v povolení k vypouštění odpadních vod pro objekt KB Alloys z 20. května 2010 bylo ověřováno, k jakým výsledkům by při stejném zadání dospěl Český imisní test (CIT).

\section{METODIKA}

Do modelu CIT byly zadány následující vstupní hodnoty:

Vypouštěné množství odpadní vody

Prưměrná šířka recipientu pod výustí

Průměrná hloubka recipientu pod výustí

Střední profilová rychlost v recipientu pod výustí

Manningův koeficient drsnosti

Vzdálenost výusti od pravého břehu

Konec chronické mísicí zóny

Konec akutní mísicí zóny

Konstanta koeficientu přičné horizontální difuze $\begin{array}{ll}\text { Koncentrace pozadí } C_{90} \vee \text { řece: } \\ \text { - pro hliník } & 6 \mu \mathrm{g} / \mathrm{l} \\ \text { - pro měd' } & 1,1 \mu \mathrm{g} / \mathrm{l}, \\ \text { - pro zinek } & 1,9 \mu \mathrm{g} / \mathrm{l} .\end{array}$

Koncentrace $C_{95}$ ve vypouštěné odpadní vodě, která byla vypočtena tak, že maximální koncentrace zjištěná u dvanácti odebraných vzorků byla vynásobena př́slušným násobitelem:

- pro hliník $348 \times 1,63=567,24 \mu \mathrm{g} / \mathrm{l}$,

- pro měd' $100 \times 1,63=163 \mu \mathrm{g} / \mathrm{l}$,

- pro zinek $27,4 \times 1,63=44,662 \mu \mathrm{g} / \mathrm{l}$.

Pro určení koncentrace s pravděpodobností nepřekročení $95 \%$ se používají statistické metody, které vycházejí z počtu odebraných vzorků. Podrobný postup výpočtu násobitele Ize nalézt na webové stránce Washington State Department of Ecology [5]. Vychází-li se napríklad z hodnot koncentrací, které jsou zjištěny ve dvanácti odebraných vzorcích, pak je násobitel 1,63.

\section{VÝSLEDKY A DISKUSE}

Výsledné faktory zředění pro konec akutní mísicí zóny a pro konec chronické mísicí zóny vypočtené modelem CIT (obr. 2) odpovídají výsledkům modelu RIVPLUM uvedeným $v$ tabulce 1, která byla převzata z podkladů pro povolení vypouštění odpadních vod z objektu KB Alloys. Na obr. 3 jsou v osmém sloupci uvedeny hodnoty, které vypočítal model CIT pro konec chronické mísicí zóny. Vypočtené hodnoty jsou v souladu s maximálními hodnotami na konci chronické mísicí zóny uvedenými v tabulce 2, která sloužila jako podklad pro povolení vypouštění odpadních vod z objektu KB Alloys. Na konci akutní mísicí zóny by model CIT vypočítal hodnoty nižší, než jsou uvedeny v tabulce 2, protože pro konec akutní mísicí zóny byl v tabulce 2 použit koeficient zředění 467, který je podstatně menší než koeficient zředění 685,1 vypočtený modelem CIT. U modelu CIT se stejně jako u modelu RIVPLUM jedná o 2D model. Odhad délky 3D zóny vychází přibližně $313 \mathrm{~m}$. Navržené délky akutní i chronické mísicí zóny jsou menší (upozorňuje na to červeně napsaná výstraha odkazující na buňku D7 na obr. 3). To znamená, že ještě nemusí dojít k dokonalému promísení ve vertikálním směru, a měl by se pro výpočet faktoru žredění použít spišse 3D model. Pro většinu praktických problémů, u kterých se počítá s průměrnou hloubkou, doporučuje Fischer [3] používat konstantu pro výpočet koeficientu vertikální difuze 0,067 . Při použití této konstanty vychází v našem případě výše uvedená vzdálenost po úplné vertikální promísení. Více než desetiletá praxe ukázala, že $\checkmark$ daném případě je ještě na hranici navržené chronické mísicí zóny výsledek získaný 2D modelem RIVPLUM (tedy i modelem CIT) príijatelný. U konce akutní mísicí zóny, který se nachází hlouběji uvnitř 3D zóny, je již mezi faktorem zředění 
získaným pomocí 2D modelu a faktorem zředění ověřeným praxí patrný podstatný rozdíl. Rutherford [4] uvádí, že u vertikálních sekundárních cirkulací v přírodních korytech vodních toků Ize očekávat zvětšení vertikálního mísení. Je však málo dat, aby se kvantifikoval jejich účinek, ale jeví se, že se konstanta koeficientu vertikální difuze nachází mezi hodnotami 0,067 až 0,33. Při použití konstanty koeficientu vertikálního mísení 0,33 by v našem případě došlo $k$ dokonalému promísení ve vertikálním směru již přibližně 64 m pod zdrojem znečištění a použití 2D modelu pro konec chronické mísící zóny ve vzdálenosti větší než $64 \mathrm{~m}$ by bylo jednoznačně odůvodnitelné.

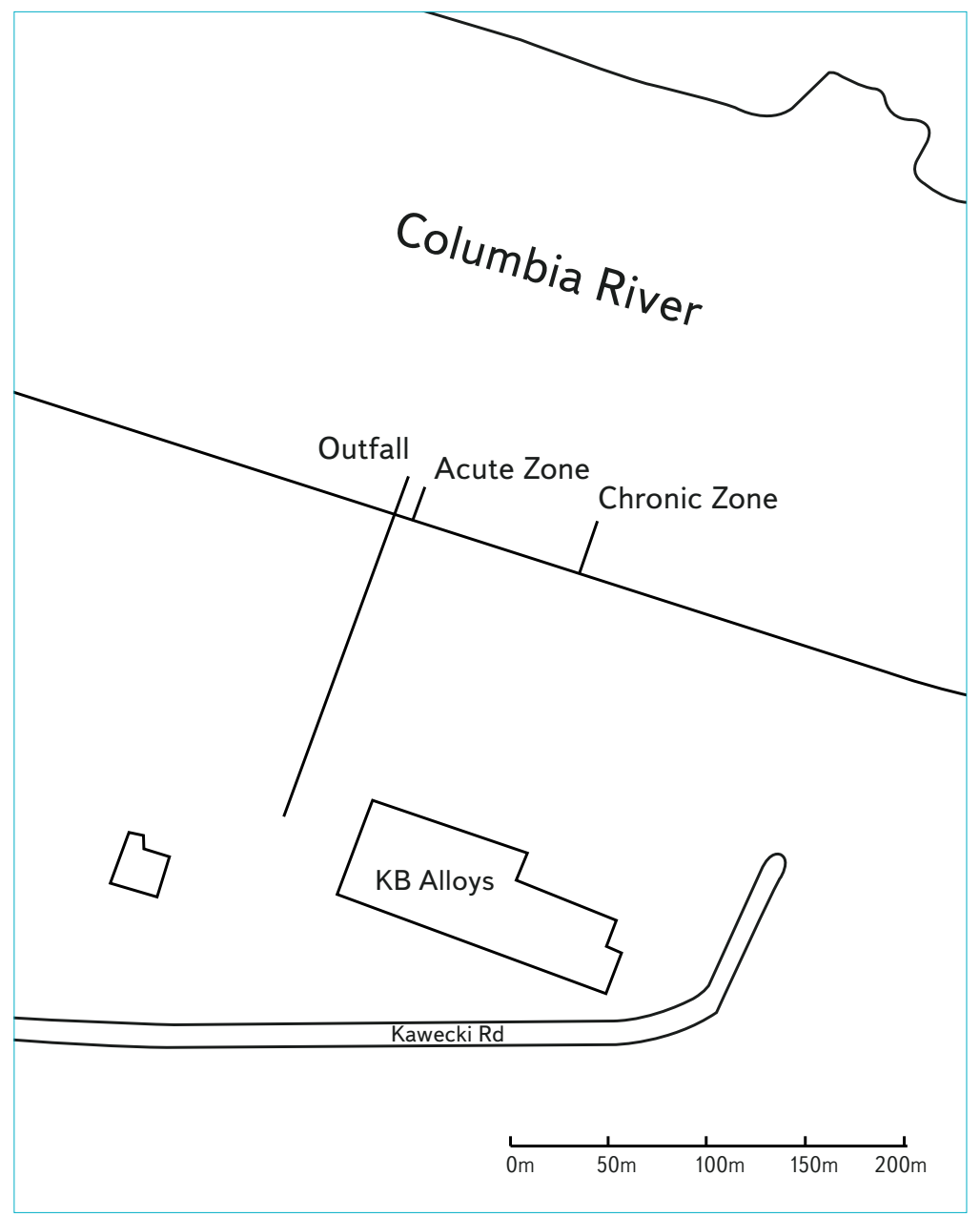

Výpočet hodnoty ve zvoleném bodě

Vzdálenost bodu od výusti dolů po proudu

\section{Výpočet hodnoty ve zvoleném bodě}

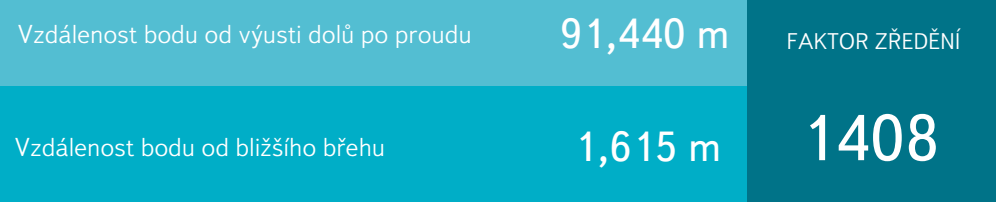

Obr. 2. Faktory žredění - výstup z modelu CIT

Fig. 2. Dilution factors - model CIT output

\section{ZÁVĚR}

Co se týká výpočtu faktoru zředění, dává model CIT přibližně stejné výsledky jako model RIVPLUM. Koncentrace $v$ toku se pak počítá na základě faktorů zředění vypočtených podle údajů o vypouštěném množství a průtokových poměrech $v$ recipientu. Je nutno upozornit, že se jedná o 2D model, který předpokládá dokonalé promísení ve vertikálním směru. To znamená, že v oblasti, ve které ještě nedojde k dokonalému promísení ve vertikálním směru, může dávat poněkud zkreslené výsledky. Pokud bude faktor zředění na konci regulační mísicí zóny vypočten nebo určen podle jiných kritérií, pak se i koncentrace $v$ recipientu vypočtené pomocí tohoto faktoru budou pochopitelně lišit od koncentrací vypočtených pomocí modelu CIT. Kritéria pro určení faktoru zředění používaná v USA Ize nalézt napríklad v [5].

\section{Poděkování}

Tento prrispěvek vznikl díky finanční podpoře věnované Ministerstvem životního prostředí České republiky výzkumnému záměru MŽP0002071101 Výzkum a ochrana hydrosféry.

Obr. 1. Situace

Fig. 1. Situation

Tabulka 1. Faktory zreděni [1]

Table 1. Dilution factors [1]

\begin{tabular}{lll} 
Metoda určení faktoru ž̌edění & $\begin{array}{l}\text { Chronický faktor zředění } \\
\text { Chronic Dilution Factor }\end{array}$ & $\begin{array}{l}\text { Akutní faktor zředění } \\
\text { Acute Dilution Factor }\end{array}$ \\
\hline Původní povolení (Previous Factsheet) & 1479 & 467 \\
\hline CORMIX VI & 644 & 43 \\
\hline RIVPLUM & 1400 & 683 \\
\hline
\end{tabular}




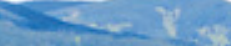

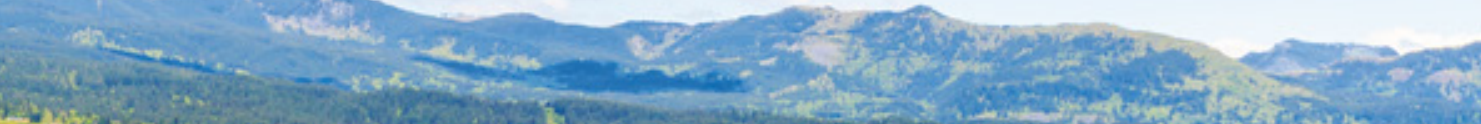

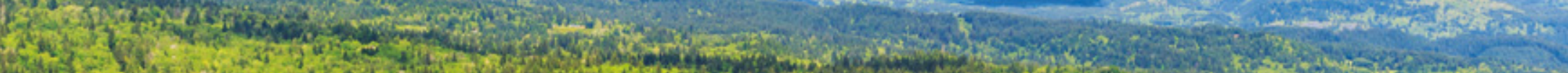

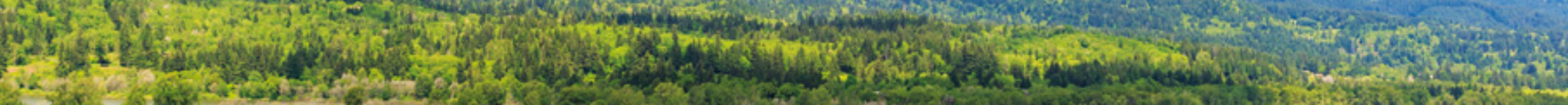

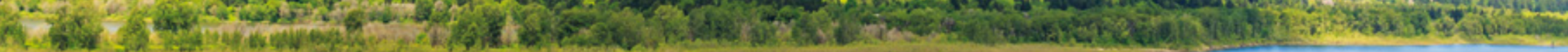

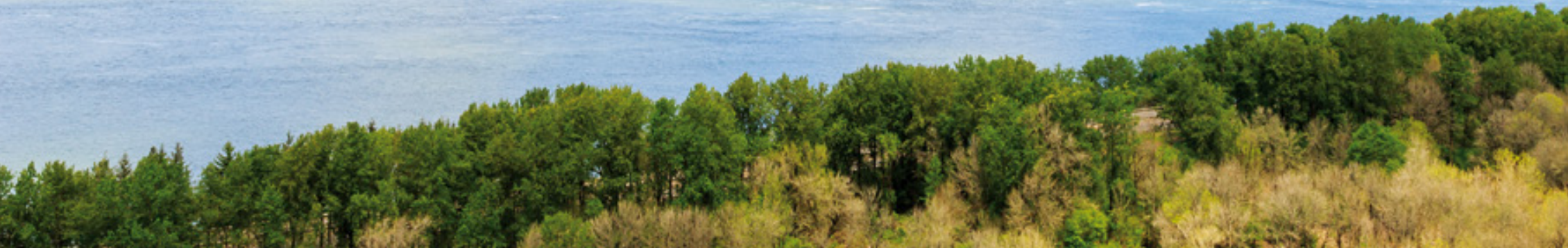
(3.4.

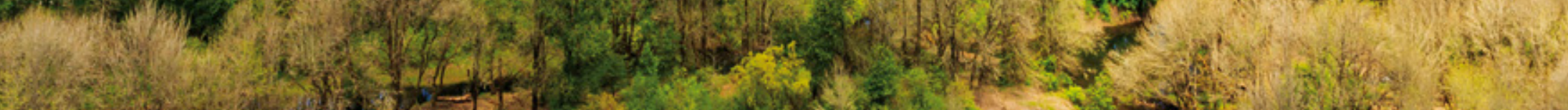 (1) $1+\sqrt{1}$ \& 11
$4 x^{2}-\frac{3}{9}$

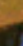
(4⿵冂八

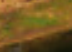
I.

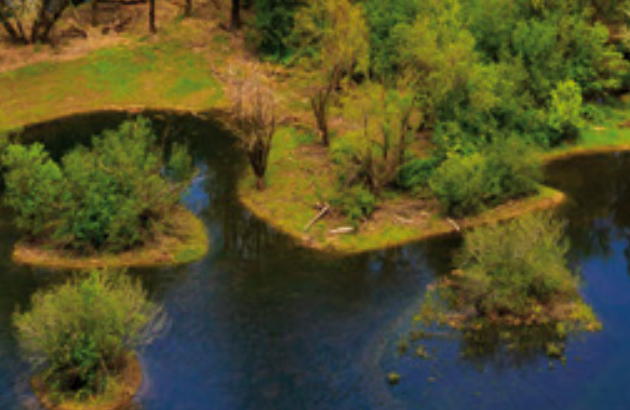

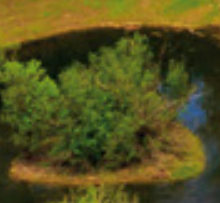 3

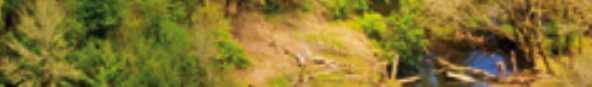




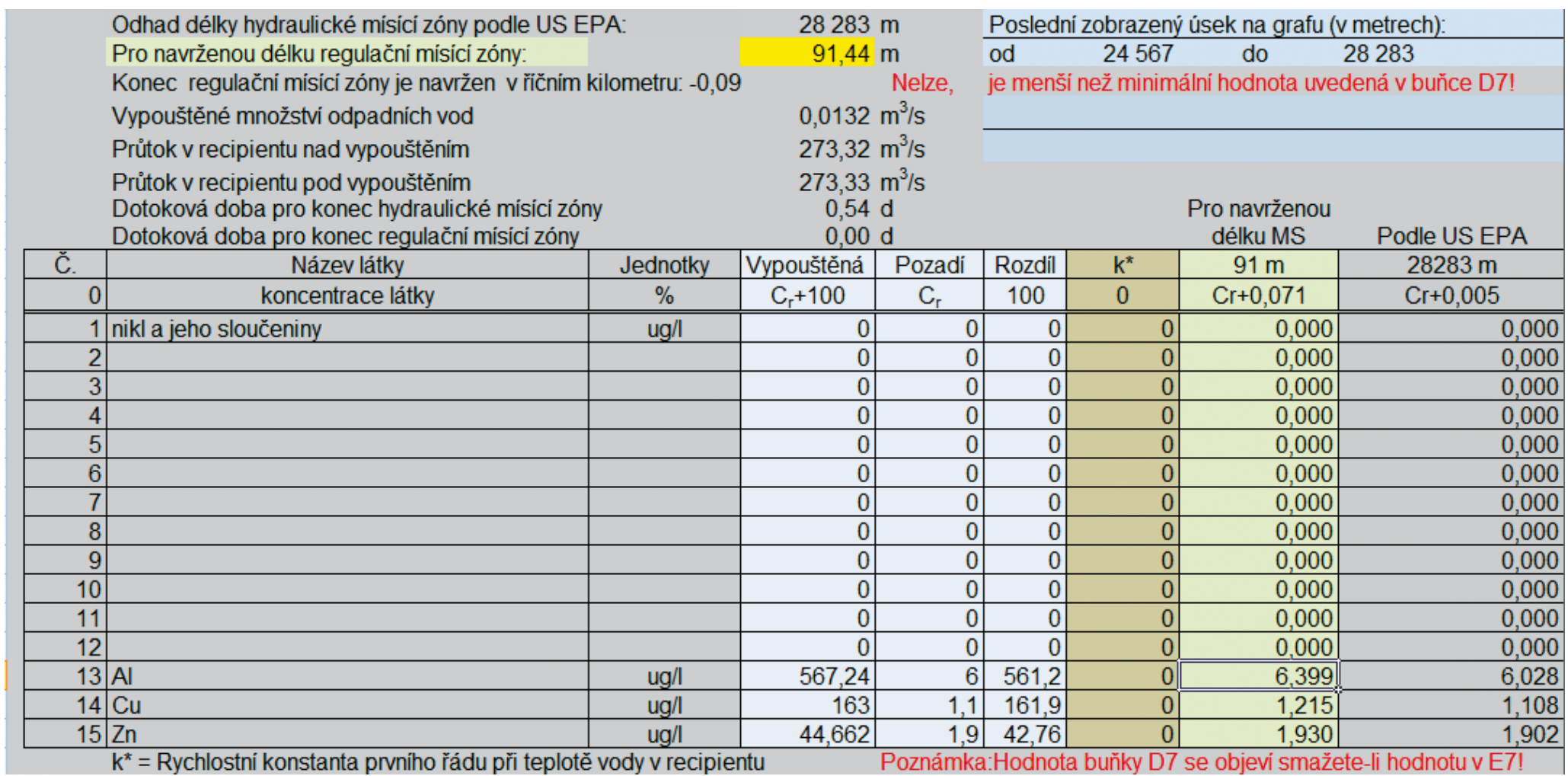

Obr. 3. Výstup z modelu CIT pro konec chronické mísicí zóny

Fig. 3. Model CIT output for boundary of the chronic mixing zone

\section{Literatura}

[1] Fact sheet for NPDES permit no. WA-000297-6. KB Alloys, LLC., 2010. Dostupné z: https://www.google $c z /$ ?gfe_rd=cr \& ei=NgM3VtjQM8ag8we5t5vACA\&gws_rd=ssl\#q=Ecology+made+in+drafting+the +proposed+NPDES+for+KB+Alloys\%2C+LLC.

[2] ŠAJER, J., MIČANÍK, T. a SÝKORA, F. Český imisní test (CIT). Druh výsledku: R - Software, předkladatel výsledku: Výzkumný ústav vodohospodářský T. G. Masaryka, veřejná výzkumná instituce, dodavatel výsledku: MŽP, konsolidovaný rok uplatnění výsledku: 2012.

[3] FISCHER, H.B. Longitudinal Dispersion and Turbulent Mixing in Open-Channel Flow. Annual Review of Fluid Mechanics, vol. 5, p. 59-78. California: University of California, Berkeley, 1973. DOI:10.1146/ annurev.fl.05.010173.000423.

[4] RUTHERFORD, J.C. Handbook On Mixing In Rivers. Hamilton Science Centre, Water and Soil Dvision, Ministry of Works and Development, Hamilton Water and Soil Miscellaneous Publication no. 26, 1981, $60 \mathrm{p}$

[5] Washington State Department of Ecology. Dostupné z: www.ecy.wa.gov/programs/wq/permits/ PermitCalcJanuary2014.xIsm

\section{Autor}

Ing. Jiří Šajer

凶jiri_sajer@vuv.cz

Výzkumný ústav vodohospodářský T. G. Masaryka, v. v. i., pobočka Ostrava

Příspěvek prošel lektorským řízením.

\section{VERIFICATION OF THE CZECH IMMISSION TEST (CIT)}

\section{SAJER, J.}

TGM Water Researche Institute, p. r. i., Ostrava branch

Keywords: mixing zone - conservative

pollution - water quality - modelling

Ecology determined the dilution factors for the KB Alloys facility over ten years ago. The development document record is not clear as to the method used to determine the values. Ecology made an attempt to model the conditions using CORMIX 6, however the software cannot model a multiport diffuser located at a distance closer to the bank than the river depth. A single port diffuser scenario, while adequate to model dilution effects on temperature, yields a dilution factor considerably less than determined previously. The conditions were then modeled using Ecology's RIVPLUM model. The assumptions inherent in this model are not recommended for a large river like the Columbia River. Using the same conditions, the RIVPLUM model derives dilution factors comparable to those contained in previous permits. Using the same conditions, the CIT model derives dilution factors on about the same level as the RIVPLUM model. 


\begin{tabular}{|c|c|c|c|c|c|c|}
\hline & $\begin{array}{l}\text { Metal Criteria } \\
\text { Transformator as } \\
\text { decimal }\end{array}$ & $\begin{array}{l}\text { Metal Criteria } \\
\text { Transformator as } \\
\text { decimal }\end{array}$ & $\begin{array}{l}\text { Koncentrace } \\
\text { pozadí (kovy } \\
\text { jako rozpuštěné) } \\
\text { Ambient } \\
\text { Concentration } \\
\text { (metals as dissolved) }\end{array}$ & $\begin{array}{l}\text { State Water } \\
\text { Standard Acute }\end{array}$ & $\begin{array}{l}\text { State Water } \\
\text { Standard Chronic }\end{array}$ & $\begin{array}{l}\text { Maximální } \\
\text { koncentrace } \\
\text { na konci akutní } \\
\text { mísicí zóny } \\
\text { Maximal } \\
\text { concentration } \\
\text { at edge of Acute } \\
\text { Mixing Zone }\end{array}$ \\
\hline Parametr & Akutní (Acute) & Chronická (Chronic) & $\mu \mathrm{g} / \mathrm{l}$ & $\mu \mathrm{g} / \mathrm{l}$ & $\mu \mathrm{g} / \mathrm{l}$ & $\mu \mathrm{g} / \mathrm{l}$ \\
\hline $\begin{array}{l}\text { Hliník } \\
\text { (Aluminium) }\end{array}$ & & & 6,000 & 750,000 & 87,000 & 7,20 \\
\hline Měd' (Copper) & 1,00 & 1,00 & 1,100 & 13,040 & 8,920 & 1,44 \\
\hline Zinek (Zinc) & 1,00 & 1,00 & 1,900 & 68,960 & 62,970 & 1,99 \\
\hline
\end{tabular}

\begin{tabular}{|l|l|l|l|l|l|}
\hline & $\begin{array}{l}\text { Maximální } \\
\text { koncentrace } \\
\text { na konci chronické } \\
\text { mísicí zóny } \\
\text { Maximal } \\
\text { concentration } \\
\text { at edge of Chronic } \\
\text { Mixing Zone }\end{array}$ & $\begin{array}{l}\text { Požadovaný limit } \\
\text { Limit required }\end{array}$ & $\begin{array}{l}\text { Pravděpodobnost } \\
\text { nepřekročení } \\
\text { hodnoty } \\
\text { vodpadní vodě } \\
\text { Effluent percentile } \\
\text { value }\end{array}$ & $\begin{array}{l}\text { Maximální } \\
\text { koncentrace } \\
\text { měřená v odpadní } \\
\text { vodě } \\
\text { Max effluent } \\
\text { concentration } \\
\text { Measured (metals } \\
\text { as total recoverable) }\end{array}$ \\
\hline Parametr & $\mu \mathrm{g} / \mathrm{l}$ & & $\begin{array}{l}\text { Variační koeficient } \\
\text { Coeff Variation }\end{array}$ \\
\hline $\begin{array}{l}\text { Hliník } \\
\text { (Aluminium) }\end{array}$ & 6,38 & NO & 0,95 & Pn & CV / \\
\hline Měd' (Copper) & 1,21 & NO & 0,95 & 348,00 & 0,60 \\
\hline Zinek (Zinc) & 1,93 & 0,95 & 0,779 & 100,00 \\
\hline
\end{tabular}

\begin{tabular}{|l|l|l|l|l|l|l|}
\hline & $\begin{array}{l}\text { Směrodatná } \\
\text { odchylka } \\
\text { Standard Deviation }\end{array}$ & $\begin{array}{l}\text { Počet vzorků } \\
\text { Number of samples }\end{array}$ & $\begin{array}{l}\text { Násobitel } \\
\text { Multiplier }\end{array}$ & $\begin{array}{l}\text { Akutní faktor } \\
\text { ž̌edéní } \\
\text { Acute Dilution } \\
\text { Factor }\end{array}$ & $\begin{array}{l}\text { Chronický faktor } \\
\text { ž̌edéní } \\
\text { Chronic Dilution } \\
\text { Factor }\end{array}$ \\
\hline Parametr & $\mathrm{s}$ & $\mathrm{n}$ & 12 & 1,63 & 467 & 1479 \\
\hline $\begin{array}{l}\text { Hliník } \\
\text { (Aluminium) }\end{array}$ & 0,55 & 12 & 1,63 & 467 & 1479 \\
\hline Měd' (Copper) & 0,55 & 12 & 1,63 & 467 & 1479 \\
\hline Zinek (Zinc) & 0,55 & & & \\
\hline
\end{tabular}

